\title{
Possible Gliclazide-Induced Water Retention with Azotemia
}

\author{
Keita Kamikubo, Rieko Takami, Tetsuya Suwa, Akihiko Sugiyama, \\ Nagatoshi Horíre and Shigeki SAKATA*
}

\begin{abstract}
An 80-year-old woman with diabetes mellitus was treated with gliclazide. Prior to the gliclazide administration, her urinary excretion of albumin, serum urea nitrogen and serum creatinine were normal. After the medication, oliguria, edema and azotemia developed. On the twenty-fourth day when the edema was severe and generalized, gliclazide administration was terminated. On the following day urinary volume increased suddenly $(5,740 \mathrm{ml} /$ day $)$. Polyuria persisted for five days. Edema improved and urea nitrogen and creatinine were normalized thereafter. Though the mechanism is not known, the clinical course suggests that gliclazide is the principal causative factor in the water retention and azotemia in this patient.
\end{abstract}

(Internal Medicine 33: 163-164, 1994)

Key words: sulfonylurea compounds, diabetes mellitus, vasopressins, edema, adverse reactions, interstitial nephritis

\section{Introduction}

In addition to hypoglycemia, sulfonylureas cause several adverse reactions such as hematological abnormalities, cutaneous reactions, gastrointestinal symptoms and hepatic reactions (1). This report describes a previously unreported adverse reaction to gliclazide. Here we describe water retention with azotemia which developed in a patient with non-insulin-dependent diabetes mellitus during gliclazide treatment and disappeared rapidly after the withdrawal of the drug.

\section{Case Report}

An 80-year-old woman with a ten-year history of diabetes mellitus was admitted to this hospital because of multiple cerebral infarction in September 1991. She had an acute myocardial infarction in 1981. On admission HbAlc was 6.4\%. She did not seem to have obvious diabetic nephropathy as indicated by normal urinary excretion of albumin ( 7 to $10 \mu \mathrm{g} /$ min), nor did she have diabetic retinopathy. She had been maintained with nasogastric tube feeding. From January to May 1992 , serum urea nitrogen concentration ( 6 to $17 \mathrm{mg} / \mathrm{dl}$ ), serum creatinine concentration $(0.4$ to $0.7 \mathrm{mg} / \mathrm{dl})$, and plasma atrial natriuretic peptide (ANP) concentration (19 to $38 \mathrm{pg} / \mathrm{ml}$ ) (normal range 10 to $40 \mathrm{pg} / \mathrm{ml}$ ) were normal and stable.

On June 9, 1992, her fasting plasma glucose concentration was $150 \mathrm{mg} / \mathrm{dl}$, serum albumin $3.4 \mathrm{~g} / \mathrm{dl}$, urea nitrogen $16.6 \mathrm{mg} /$ $\mathrm{dl}$, creatinine $0.6 \mathrm{mg} / \mathrm{dl}$, Na $137 \mathrm{mEq} / \mathrm{l}$, and $\mathrm{K} 3.7 \mathrm{mEq} / \mathrm{l}$. Gliclazide $(20 \mathrm{mg} / \mathrm{day})$ was started on June 27 . Two days earlier, very mild edema probably due to hypoalbuminemia was noticed in the back. After the initiation of gliclazide, the edema progressively worsened (Fig. 1). Blood urea nitrogen and creatinine increased gradually. Two weeks after the start of gliclazide administration when albumin was $2.5 \mathrm{~g} / \mathrm{dl}, \mathrm{Na} 137$ $\mathrm{mEq} / \mathrm{l}, \mathrm{K} 3.5 \mathrm{mEq} / \mathrm{l}$, and edema was generalized, furosemide $(20 \mathrm{mg} /$ day $)$ and spironolactone $(25 \mathrm{mg} /$ day $)$ were started, and the dose of gliclazide was increased to $40 \mathrm{mg} /$ day. Four days later, dopamine was started. Twenty days after the initiation of gliclazide when the measurement of urinary volume was started, oliguria ( $400 \mathrm{ml} /$ day) was noticed. Serum $\mathrm{Na}$ was $135 \mathrm{mEq} / \mathrm{l}$ and $\mathrm{K}$ was $4.2 \mathrm{mEq} / \mathrm{l}$. Doses of furosemide and spironolactone increased 2-fold. There was no improvement in edema or urinary volume. Microscopic hematuria and columnar epithelial cells in the urinary sediment were noticed. Twenty-four days after the start of gliclazide, oliguria and hypoalbuminemia (2.5 $\mathrm{g} / \mathrm{dl})$ persisted, hyponatremia $(127 \mathrm{mEq} / \mathrm{l})$ developed, serum $\mathrm{K}$ was $4.3 \mathrm{mEq} / \mathrm{l}$, urea nitrogen was $49.6 \mathrm{mg} / \mathrm{dl}$, and creatinine was $2.2 \mathrm{mg} / \mathrm{dl}$. Plasma ANP was high $(100 \mathrm{pg} / \mathrm{ml})$, and plasma vasopressin concentration $(0.8 \mathrm{pg} / \mathrm{ml})$ was appropriate for the plasma osmolality (reference range 0.5 to $3.0 \mathrm{pg} / \mathrm{ml}$ ). Urinary excretion of $\mathrm{N}$-acetyl-3-D-glucosaminidase $(19 \mathrm{U} / \mathrm{l})$ was high (normal range 1 to $5 \mathrm{U} / \mathrm{l}$ ). Gliclazide administration was termi-

From the Department of Internal Medicine, Takayama Red Cross Hospital, Takayama and *the Third Department of Internal Medicine, Gifu University School of Medicine, Gifu

Received for publication August 9, 1993; Accepted for publication January 6, 1994

Reprint requests should be addressed to Dr. Keita Kamikubo, the Division of Endocrinology and Metabolism, Department of Internal Medicine, Takayama Red Cross Hospital, Tenmancho, Takayama, Gifu 506 


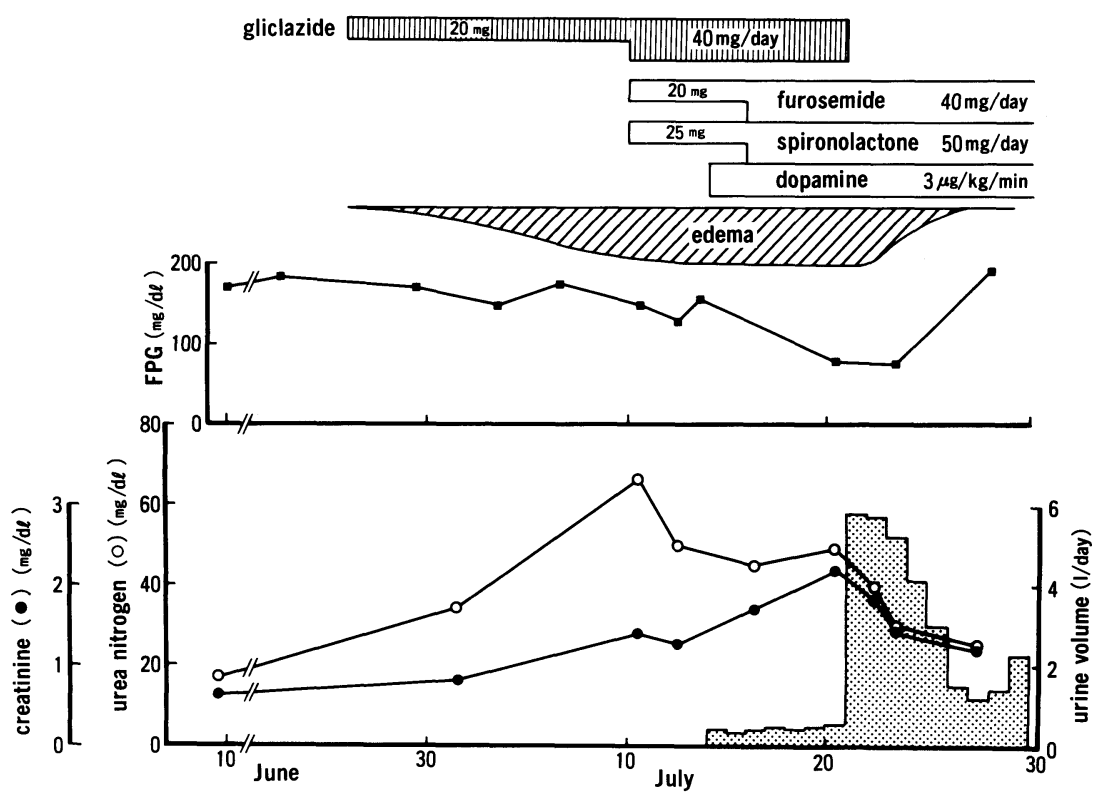

Fig. 1. Clinical course.

FPG: fasting plasma glucose.

nated on that day. On the following day, the urinary volume increased suddenly $(5,740 \mathrm{ml} /$ day $)$. Polyuria persisted for five days. Edema improved and urea nitrogen and creatinine levels started to decline. Two weeks after the termination of gliclazide administration, albumin was $3.0 \mathrm{~g} / \mathrm{dl}$, urea nitrogen $18.7 \mathrm{mg} / \mathrm{dl}$, creatinine $0.7 \mathrm{mg} / \mathrm{dl}, \mathrm{Na} 136 \mathrm{mEq} / \mathrm{l}$, and K $4.6 \mathrm{mEq} / \mathrm{l}$.

There was no massive proteinuria, fever, rash, eosinophilia nor liver dysfunction during the clinical course. Serum Ca corrected with albumin was normal during the course. From August to October1992, serum urea nitrogen, creatinine, Na, K, and plasma ANP were normal; urinary excretion of N-acetyl-BD-glucosaminidase was slightly high (6 to $11 \mathrm{U} / \mathrm{l})$. Lymphocyte stimulation test with the same gliclazide agent was negative.

\section{Discussion}

The most remarkable finding in this patient is the abrupt polyuria following the withdrawal of gliclazide. Though the hypoalbuminemia probably due to malnutrition and possible heart failure might have played a role, the clinical course clearly suggests that gliclazide was the principal causative factor of the water retention. It is unlikely that the sudden 10 -fold increase of urinary volume was solely due to the diuretics and dopamine which had been administered for about one to two weeks. There was no event such as termination of arrhythmia which may cause a sudden improvement in cardiac function. Since urinary glucose was negative, glucose osmouresis can not explain the polyuria after the withdrawal of gliclazide. Due to the spontaneous polyuria, incomplete obstruction of the urinary tract is unlikely for the mechanism of oliguria and azotemia.

Multiple mechanisms may have been involved in the possible gliclazide-induced water retention. The microscopic hematuria, columnar epithelial sediment and transient increase in $\mathrm{N}$-acetyl- $\beta$-D-glucosaminidase excretion provide evidence for renal injury which probably was in part responsible for the azotemia and the water retention. The mechanism of renal injury is not clear. Though there was no allergic reaction such as rash or eosinophilia, drug-induced acute interstitial nephritis can not be ruled out. In addition to the renal injury, the abrupt polyuria may suggest that rapidly reversible functional disturbance of water metabolism was also involved in the development of water retention. Chlorpropamide and tolbutamide have been shown to cause water retention by stimulating vasopressin secretion and by augmenting the renal action of the hormone (2-4). Hyponatremia and reduced water excretion have also been reported with glipizide, though the mechanism may differ from that seen with chlorpropamide (1). it is not known whether gliclazide has such actions or not. The plasma vasopressin concentration was appropriate for the plasma osmolality in this patient. However, there remains the possibility that gliclazide caused other functional disturbance of the water metabolism in this patient. To the best of our knowledge, this is the first report of possible gliclazide-induced water retention. We should be aware of possible water retention in patients under treatment with gliclazide.

\section{References}

1) Paice BJ, Paterson KR, Lawson DH. Undesired effects of the sulphonylurea drugs. Adverse Drug React Acute Poisoning Rev 1: 23, 1985.

2) Garcia M, Miller M, Moses AM. Chlorpropamide-induced water retention in patients with diabetes mellitus. Ann Intern Med 75: 549, 1971.

3) Hagen GA, Frawley TF. Hyponatremia due to sulfonylurea compounds. J Clin Endocrinol Metab 31: 570, 1970.

4) Moses AM, Miller M. Drug-induced dilutional hyponatremia. N Engl J Med 291: 1234, 1974. 